\title{
DEATH AND REBIRTH OF A LEPROSY SERVICE
}

\section{RICHARD C. BROWNE*}

The past 15 years witnessed the disintegration of several leprosy services in Central Zaire. Programmes of case finding, treatment and rehabilitation that were at one time among the most respected in Central Africa, have vanished. Two unrelated events coincided at one point in time to produce this unfortunate situation. First, the independence proclaimed in 1960 released a wave of social unrest which culminated in the intertribal wars of the mid 1960's. There was interruption of communications; transport of supplies and personnel was hindered. Medical workers and patients located in some areas were forced to flee to their homelands. Records were destroyed and clinics were shut down. Treatment became sporadic and patients were lost.

Second, the closing of leprosy villages or "colonies" came into fashion. Ambulatory home treatment was encouraged and adopted. Patients were sent back to their villages. Appointments may have been made for their periodic return; but the danger of travel and the deterioration of roads precluded this from happening regularly. These events took place at Bulape in the West Kasai province.

Bulape, an isolated mission hospital, was established in 1920. For years it had received leprosy patients brought in by Belgian sanitation workers from village screening surveys. The estimated prevalence of leprosy for the area was greater than one per thousand inhabitants. Missionary physicians at Bulape cooperated with government workers in standardized treatment practices. Eventually a colony of leprosy patients grew up adjacent to Bulape Hospital. A separate clinic building was constructed. A leprosy nurse was appointed. Special gifts of food and clothing were donated to the patients by missionaries and by philanthropic societies. At its apogee in the 1950's there were several hundred resident leprosy patients under treatment at Bulape.

In 1960 the country was declared independent of Belgium. Sanitation workers withdrew and were not replaced. New admissions to the leprosy service at Bulape fell off. Younger missionary physicians arrived who were not accustomed to the ways of managing a leprosy service. The leprosy nurse departed; and ongoing leprosy care was "integrated" into the general outpatient clinics of Bulape Hospital. In 1964 there was renewed intertribal fighting with bloodshed in the Bulape area. Physicians were evacuated temporarily. Treatment was interrupted and many patients fled. Soon thereafter, the leprosy colony was closed. The 25 patients who remained were sent away. All of them actually departed except a handful of old, non-active cases with deformities. These people simply moved 1 kilometre away and continued a wretched existence without special consideration or care.

When the author arrived at Bulape in 1973 he found no records of old or present leprosy cases. There were no active cases known. Five elderly people with deformed feet and hands constituted the entire leprosy case load. They earned a meagre living by making charcoal and selling it to the local citizens. Bulape Hospital itself was a thriving institution. It consisted of 100 beds. It offered full obstetrical and surgical services. There was an active paediatric unit complete with

* Bulape Hospital, Kananga, Zaire.

Received for publication 16 October, 1975. 
a nutrition rehabilitation centre. Road teams touched some 20,000 people in a rural community health programme. Yet in spite of all this clinical activity, the leprosy service at Bulape was dead!

The American Leprosy Missions (ALM) encouraged a rebirth of this service. For the new missionary physician, ALM underwrote 1 month's specialized training in Addis Ababa (ALERT). ALM then secured a lift of $\$ 6000$ for equipment, transport, and personnel development over a 3 year period. The new service was to be integrated with the community health project at Bulape. A male nurse was recruited. He was sent for training at Kivivu, Zaire; and guaranteed a salary commensurate with his specialized training and responsibility.

The primary goal of the resurrected leprosy service is to find and to place under treatment all active cases of leprosy in the Bulape area. To do this required the establishing of a reputation of confidentiality, kindness and effectiveness. The 5, old burnt-out cases were helpful in doing this. They were brought to the out-patient clinic for skin care and physical therapy. The new nurse won their respect. Soon, other old cases showed up. Then a person with active lepsory came in, was examined, educated in his disease and sent home with medicines. He has continued to return for routine follow-up. As the reputation of the revived leprosy service spread, more people came in. Some with non-leprous lesions felt free to present for diagnosis of other skin problems.

Next, a series of village screening surveys was organized as a part of the community health effort. People were invited to appear for "skin inspection"; most do not fear this procedure if done discreetly. More and more people with active disease were discovered and enrolled. Although patients were often asked to come to the hospital for biopsy or other diagnostic studies, all were left in their home village for treatment.

In the $1 \frac{1 / 2}{2}$ years since the Bulape leprosy service was re-born, 4 additional treatment posts have been set up. These posts allow patients to be examined and treated closer to their homes. At the time of writing 135 leprosy patients are enrolled and under surveillance. Most patients follow their treatment satisfactorily. They appear pleased with the care they are receiving.

The future of this modest programme requires its merger with the general services of Bulape Hospital. Classes and demonstrations conducted by the physician and leprosy nurse have now begun to familiarize other hospital workers with the diagnosis and management of the disease. It is clear though, that this revival of interest in leprosy could not have been accomplished without persornnel with specialized training. Without someone on the staff whose primary concern is leprosy, the service would again be relegated to a low priority. The leprosy service at Bulape would then die a second death. 